\title{
Ingenuous Subjection
}





\title{
Ingenuous Subjection
}

Compliance and Power in the Eighteenth-Century Domestic Novel

\author{
HELEN THOMPSON
}

\section{$\overline{\text { PENN }}$}

University of Pennsylvania Press

Philadelphia 
Copyright (c) 2005 University of Pennsylvania Press

All rights reserved

Printed in the United States of America on acid-free paper

$\begin{array}{llllllllll}10 & 9 & 8 & 7 & 6 & 5 & 4 & 3 & 2 & 1\end{array}$

Published by

University of Pennsylvania Press

Philadelphia, Pennsylvania 19104-4112

Library of Congress Cataloging-in-Publication Data

Thompson, Helen, 1967-

Ingenuous subjection : compliance and power in the eighteenth-century domestic novel / Helen Thompson.

p. $\mathrm{cm}$.

Includes bibliographical references (p. ) and index.

ISBN 0-8122-3891-5 (cloth : acid-free paper)

1. English fiction-18th century-History and criticism. 2. Feminism and literatureGreat Britain-History-18th century. 3. Women and literature-Great Britain-

History-18th century. 4. Domestic fiction, English-History and criticism. 5. Power

(Social sciences) in literature. 6. Family in literature. 7. Women in literature. I. Title.

PR858.F45T47 2005

$823 ' .5093552-\mathrm{dc} 22$

2005042299 